Moch. Sugiarto, et al. /Animal Production. 19(2):127-134, 2017

ISSN 1411-2027

\title{
The Competitiveness of Beef Cattle Business on Various Agro-Ecological Zones in Tegal Regency
}

\author{
Moch. Sugiarto ${ }^{1}$, Yusmi Nur Wakhidati ${ }^{1}$, Alif Einstein ${ }^{1}$ and Khaerudin ${ }^{2}$ \\ ${ }^{1}$ Faculty of Animal Sciences, Jenderal Soedirman University, Purwokerto \\ ${ }^{2}$ Marine, Fisheries, and Animal Husbandry Office of Tegal Regency \\ *Corresponding author email: zoegic@yahoo.com
}

\begin{abstract}
The competitiveness of livestock business is one strategic issue to guarantee the empowerment and sustainability of small scale beef cattle business. The study conducted on the competitiveness of beef cattle business in Tegal regency aims at (1) identifying the competitiveness of beef cattle business in various agro-ecological zones and (2) analyzing factors influencing the business competitiveness. This study employs a survey method to 100 beef cattle farmers in Tegal Regency. The respondents are selected using a stratified random sampling technique based on the agro-ecological zones (highland, lowland, and coastal areas). The observed variables are business efficiency, farmers' age, farmers' education, farming experience, number of family members, and number of cattle. The data are processed using ANOVA and multiple linear regressions. The beef cattle business in Tegal Regency is quite competitive which is characterized with the business efficiency by 1.39 . The beef cattle business at the highlands has a higher competitiveness than that at the other agro-ecological zones $(P<0.01)$. The competitiveness of beef cattle business is influenced by the farmers' age $(P<0.05)$, as well as the farming experience and number of cattle ( $P$ $<0.01)$. The development of beef cattle business scale accompanied by the development of livestock production technical ability should be made to strengthen the competitiveness of beef cattle business in Tegal regency.
\end{abstract}

Keywords: business efficiency, agro ecological, business scale

Abstrak. Daya saing usaha ternak merupakan salah satu isu strategis untuk menjamin pemberdayaan dan keberlanjutan usaha peternakan sapi potong skala kecil. Penelitian yang dilakukan terkait daya saing usaha peternakan sapi potong di Kabupaten Tegal bertujuan untuk (1) mengidentifikasi daya saing usaha ternak sapi potong di berbagai zona agroekologi dan (2) menganalisis faktor-faktor yang mempengaruhi daya saing usaha sapi potong di Kabupaten Tegal. Penelitian ini menggunakan metode survei terhadap 100 peternak sapi potong di Kabupaten Tegal. Responden dipilih dengan menggunakan teknik stratified random sampling berdasarkan zona agroekologi (dataran tinggi, dataran rendah, dan daerah pesisir). Variabel yang diamati adalah efisiensi usaha, umur peternak, pendidikan peternak, pengalaman beternak sapi potong, jumlah anggota keluarga, dan jumlah ternak sapi potong. Data diolah menggunakan ANOVA dan regresi linier berganda. Usaha ternak sapi potong di Kabupaten Tegal cukup kompetitif yang ditandai dengan efisiensi usaha sebesar 1,39 . Usaha ternak sapi potong di dataran tinggi memiliki daya saing yang lebih tinggi daripada di zona agro-ekologi lainnya $(P<0,01)$. Daya saing usaha ternak sapi dipengaruhi oleh umur petani $(P<0,05)$, pengalaman beternak dan jumlah ternak $(P<0,01)$. Penambahan skala usaha peternakan sapi potong yang disertai dengan peningkatan kemampuan teknis produksi ternak harus dilakukan untuk memperkuat daya saing usaha ternak sapi potong di Kabupaten Tegal. Kata kunci : efisiensi usaha, agroekologi, skala usaha

\section{Introduction}

Tegal regency is a region based on agriculture which occupies various geographical areas or agro-ecological zones ranging from the highlands to the coastal areas. These geographical conditions result in differences of natural resource availability, especially the animal feeds and human resources for the beef cattle business. The diversity of production 
input availability for the development of beef cattle business becomes one factor causing the diversity of beef cattle population among subdistricts in Tegal Regency. Central Bureau of Statistics of Tegal Regency (2016) has calculated the number of beef cattle farmers which are equal to 3,699 farmers with 10,059 beef cattle population. That beef cattle population shows a positive growth by 3.9 percent per year within the period of 2013-2015.

The beef cattle business in Tegal regency is cultivated to produce meat and is managed with a business scale of 1-5 cows per farmer. Dixon et al. (2004) suggest that the small-scale farmers are characterized by the livestock ownership between 1-10 cows utilizing limited technology and external input. The limited business scale may become one challenge to improve the business efficiency, farmers' household income and business competitiveness. The competitiveness of livestock business is an important issue in maintaining the sustainability of small scale cattle business in rural areas. Business competitiveness is closely related to improve the business efficiency and productivity. The competitiveness of beef cattle business is the ability of beef cattle (micro level) business unit to compete in the bigger challenging condition. The ability of beef cattle business unit to compete may result in its business sustainability. Alvarez and Arias (2014) explains that the efficiency and productivity are frequently used as the competitiveness indicator which essentially measures the potentials of input decrease and output increase.

Business efficiency is closely related to the availability of beef cattle input production with low economic value. The condition of agroecological zones which appropriate for the livestock production may provide abundant input production with lower cost. Business scale expansion greatly requires the agro-ecological zones which support the beef cattle production system. The identification of agro-ecological zones which are appropriate for beef cattle production and demographic social factors influencing the business efficiency may help formulate the sustainability strategies for small scale cattle business in Tegal regency. Marques et al. (2011) state that competitiveness should pay more attention to the efficiency which is specified by the various production factors including the management scale. Thus, the study on strengthening the competitiveness of small-scale cattle business in Tegal regency aims at (1) identifying the competitiveness of beef cattle business in various agro-ecological zones, (2) to analyze factors influencing the competitiveness of beef cattle business in Tegal Regency.

\section{Materials and Methods}

The study on strengthening the competitiveness of small-scale cattle business in Tegal Regency is conducted by a survey method through interviews using questionnaires and observation on 100 beef cattle farmers. Sample areas are determined using a stratified random sampling based on the altitude of the areas. Strata 1 (coastal area/<250 $\mathrm{m}$ above the sea level) covers Kramat, Suradadi and Warureja Subdistrict, strata 2 (lowland/250-750 m above the sea level) covers Adiwerna, Dukuhturi, Talang, Tarub, Pagerbarang, Dukuhwaru, Slawi, Lebaksiu, a part of Surodadi, Warurejo, Kedungbanteng and Pangkah sub-district, strata 3 (highlands/mountains> $750 \mathrm{~m}$ above the sea level) covers Jatinegara, Margasari, Balapulang, Bumijawa, Bojong and a part of Pangkah, and Kedungbanteng sub-district. Each stratum is selected by 20 percent of sub-districts classified into each strata. Respondents are selected by $20 \%$ of the beef cattle farmers classified in each selected sub-district. Furchan (2007) states that the sampling made of at least 20 percent of the 
population have described the actual population condition.

The variables observed in this research are business efficiency, farmers' age, education, ranching experience, number of family members, and number of cattle. The data is processed using Return to Cost Analysis, ANOVA and multiple linear regression approach.

\section{Results and Discussion}

\section{Respondents' Characteristics}

Beef cattle business in Tegal regency is made with traditional fattening cultivation pattern with the limited ownership of 1-5 cows. The farmers should buy 1 year old cow and should be cultivated for 6 months by providing forage and concentrate in limited quantities. Due to the beef cattle fattening pattern, the farmers in Tegal District have various characteristics on age, education, number of family members, farming experience, and number of cattle cultivated. Each characteristic is described in detail as follows:

\section{Farmers' Age}

Age is the farmers' maturity level in making a decision which also influences their experience. The older the age of a person the more experience they may have. Age condition also provides a description on the farmers' physical capability in performing the beef cattle ranching business.

Most respondents ( 82 percent) are at the range of productive age (15-56 years old) who guarantee the availability of workers with sufficient physical capability to manage the beef cattle business. This condition is a potential to be utilized in the development of beef cattle ranching business. Otieno et al. (2012) suggests that the farmers' age positively influences the business performance as the older farmers may have more experience and accumulated knowledge to utilize input more efficiently.

Beef cattle farmers in Tegal Regency have an average age of 48.1 years old (still within the range of productive age). Makatita (2013) states that the number of respondents who are still within the productive age group may be considered as the main capital to develop a livestock business.

\section{Education Level}

Formal education is the length of time the respondents complete the highest education level expressed in year unit. The education levels are classified into elementary school (SD), junior high school (SMP), senior high school, (SMA), and higher education (PT).

Table 1. Beef Cattle Farmers' Age in Tegal Regency

\begin{tabular}{ccc}
\hline Farmers' age & Frequency & Percentage (\%) \\
\hline$<15$ years old & 0 & 0 \\
$15-56$ years old & 82 & 82 \\
$>56$ years old & 18 & 18 \\
\hline
\end{tabular}

Source: processed primary data (2016)

Table 2. Beef Cattle Farmers' Education level in Tegal Regency

\begin{tabular}{lcc}
\hline Education Level & Frequency & Percentage (\%) \\
\hline$<6$ Years (elementary school) & 16 & 16 \\
6 s/d 9 years (junior high school) & 75 & 75 \\
10 s/d 12 years (senior high school) & 8 & 8 \\
$>12$ years (university) & 1 & 1 \\
\hline
\end{tabular}

Source: processed primary data (2016) 
Table 2 explains that most beef cattle farmers (84 percent) in Tegal Regency minimally graduated from junior high school. That good education level may become one important capital for the farmers to improve the management of beef cattle business. Sanaky (2003) states that the relatively high education and younger age may encourage the farmers to think broader that may result in the farmers' innovation and more efficient performance orientation. Higher education is one important capital in developing the beef cattle business as one entrepreneurship form. Mohammed and Ortmann (2005) identify that education encourages the farmers to have a willingness to take the business risks.

\section{Number of Family Members}

The number of families is a description of the number of individuals living in a house with a farmer as the head of the family. The number of family members of beef cattle farmers in Tegal Regency varies between 1-6 people.

Most farmers in Tegal Regency have $2-4$ family members (68 percent). The philosophy "banyak anak banyak rejeki" (more children may generate more fortunes) is less agreed by the beef cattle farmers in Tegal Regency. Limited assets and natural resources become one consideration of the farmers to have more family members. Family member positively influence the availability of family workers. However, more family members may reduce the wide of the areas used for the livestock ranching business. Zuman et al. (2012) state that the bigger the number of family members encourages the farmers to maintain their beef cattle business.

\section{Farming Experience}

Farming experience is the length of a farmer performs his/her farming activities calculated starting from his/her initial farming activities up to this research is conducted. Farmers with adequate farming experience may have more understanding on their running farm business. Most farmers (86 percent) have experienced cultivating beef cattle business for quite long ( $>$ 10 years). This condition shows that the beef cattle farm business has become their culture and been passed down from generation to generation.

Someone's farming experience has an important role in obtaining more information, especially on innovation. Luanmase et al. (2011) state that farming experience may improve the farming motivation. More farming experience encourages the farmers to expand their business and maintain the sustainability of their business. Iyai et al. (2016) also add that the inexperienced farmers may face difficulties in maintaining their livestock business.

Table 3. Number of Family Members of Beef Cattle Farmers in Tegal Regency

\begin{tabular}{lcc}
\hline Number of Family Members & Frequency & Percentage (\%) \\
\hline$<2$ people & 7 & 7 \\
2 s/d 4 people & 68 & 68 \\
$>4$ people & 25 & 25 \\
\hline
\end{tabular}

Source: processed primary data (2016)

Tabel 4. Beef Cattle Farmers' Experience in Tegal Regency

\begin{tabular}{lcc}
\hline Farmers' Experience & Frequency & Percentage (\%) \\
\hline$<10$ year & 14 & 14 \\
10 s/d 20 year & 63 & 63 \\
$>20$ year & 23 & 23
\end{tabular}

Source: processed primary data (2016) 


\section{Number of Cattle}

The number of the cattle provides a description on the number of beef cattle owned by the farmers and is expressed in animal unit $(A U)$. The cow's weight above $325 \mathrm{~kg}$ is considered $1 \mathrm{AU}$, younger cow (age 1 year) = $0.5 \mathrm{AU}$, and calf (age below 1 year) $=0.25 \mathrm{AU}$.

Beef cattle farmers in Tegal Regency are classified into small-scale farmers. Most farmers (53 percent) have a beef cattle business scale of between 2-4 Animal Unit (AU) or 2-4 adult cows. The mean value of beef cattle owning scale per farmer is 3 Animal Unit. Bawinto et al. (2016) explains that it is ideally to cultivate 4 adult cows (4 animal units) per farmer. The livestock owned by the farmers is less in number due to the limited cultivation time, limited feed supporting capacity, and the limited availability of 1.5 year old cow which price is approximately 7 million rupiahs. The limited beef cattle may result in the reduced efficiency of beef cattle business. Bahta and Baker (2015) state that the increasing number of livestock may improve the profit and efficiency of the beef cattle business.

\section{The Competitiveness of Beef Cattle Business}

The competitiveness of a commodity is frequently measured using the comparative and competitive superiority approach. Comparative superiority is a concept developed by David Ricardo to explain the efficiency of open resource allocation (Krugman and Obstfeld, 2000). The competitiveness of beef cattle business reflects the ability of beef cattle business to compete in business based on the efficiency of production input utilization to produce a number of production outputs. The agro-ecological zone differences lead to the input availability and the efficiency level differences of the users.

Beef cattle business on 3 adult cows scale with the fattening pattern requires an average cost of Rp. 71,797,391.92 per production year. The beef cattle business in highland areas (> $750 \mathrm{~m}$ above the sea level) requires lower production costs when compared to those of the other regions. The average revenue made by each beef cattle rancher in Tegal regency is Rp. $100,140,416.67$ per year. In general, the beef cattle business management with the fattening pattern in Tegal regency for the ownership of 3 cows may generate a total profit

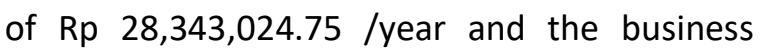
efficiency of 1.3 .

Table 5. Description of Number of the Cultivated Cattle in Tegal Regency

\begin{tabular}{lcc}
\hline Number of Livestock (Animal Unit/AU) & Frequency & Percentage (\%) \\
\hline$<2 \mathrm{AU}$ & 40 & 40 \\
$2-4 \mathrm{AU}$ & 53 & 53 \\
$>4 \mathrm{AU}$ & 7 & 7 \\
\hline
\end{tabular}

Source: processed primary data (2016)

Table 6. The Comparison of Cost, Revenue, and Efficiency of the Beef Cattle Business in Various Agro-ecological Zones in Tegal Regency

\begin{tabular}{lccc}
\hline Agro-ecological zones & Total Cost & Revenue & Business Efficiency \\
\hline High Agro-ecology $(>750 \mathrm{~m}$ asl) & $\mathrm{Rp} \mathrm{42,566,093.6}$ & $\mathrm{Rp} \mathrm{71,506,250}$ & $1.68^{*}$ \\
Low Agro-ecology $(250-750 \mathrm{~m}$ asl) & $\mathrm{Rp} \mathrm{74,601,770.3}$ & $\mathrm{Rp} \mathrm{103,317,500}$ & $1.38^{*}$ \\
Coastal Agro-ecology $(<250 \mathrm{~m}$ asl) & $\mathrm{Rp} \mathrm{98,224,311.8}$ & $\mathrm{Rp} \mathrm{125,597,500}$ & $1.28^{*}$ \\
\hline
\end{tabular}

* Significance at 0.05 
Small scale beef cattle business in high agroecological zones (> $750 \mathrm{~m}$ above the sea level) generate the profit average of Rp. $28,940,156.38$ per year with relatively higher business efficiency by 1.68 ( $P<0.05)$ when compared to that of the other regions. In the coastal agro-ecological zones, the beef cattle business generates the lowest profit of $\mathrm{Rp}$. $27,373,188.20$ per year with business efficiency of 1.28. This condition is supported by the higher forage production in the higher regional areas by $321,215.19 \mathrm{~kg} /$ year when compared to the other agro-ecological zones. Hadiana (2007) states that the natural resources may support the grass availability that the production costs may be decreased and the livestock business may become more efficient.

\section{The Factors Influencing the Competitiveness of Beef Cattle Business}

The sustainability of small-scale beef cattle business in Indonesia has become a strategic issue especially to nationally meet the required amount of meat. The increasing competitiveness of small-scale beef cattle business may guarantee the sustainability of beef cattle ranching business. The optimization of production inputs to generate a number of outputs due to the beef cattle business may result in business efficiency. Marjaya (2015) states that one efficiency indicator is that when a certain number of outputs may be generated by fewer input combinations may also minimize the production costs without reducing the outputs. With a minimum production cost, the more competitive output prices may be obtained.

The beef cattle business in Tegal regency has adequate competitiveness with its business efficiency level by 1.39 . The addition of input production of Rp. 1.00 may increase the revenue by Rp. 1.39. This business competitiveness should always be well maintained considering to the important factors which may result in the beef cattle business efficiency changes.

The identification of internal and external factors to improve the competitiveness of small-scale beef cattle business is greatly important. Based on the multiple regression analysis, the equation of line $Y=1.328-$ $0.008 X_{1}+0.013 X_{2}+0.031 X_{3}+0.016 X_{4}+0.122 X_{5}$ may be used to predict the beef cattle business efficiency changes. Partially, the farmers' age, farming experience and beef cattle business scale significantly influences $(P<0.01)$ the beef cattle business efficiency. The age significant increase $(P<0.01)$ negatively influences the efficiency of farmers, especially those above the productive age. Productive age may provide better physical and intellectual capabilities than nonproductive ages that they may cultivate more livestock with more productive results. Someone's learning ability may be accelerated by his/her increasing age, yet decreasing when he/she reaches 55 years old. Due to the farmers' age which is still generally classified into the productive age then the farmers' ability

Table 7. The Influence of Independent Variables on The Beef Cattle Business Efficiency in Tegal Regency

\begin{tabular}{lcc}
\hline Variable & Regression Coefficient & Significance \\
\hline Age & -0.008 & $0.028^{* *}$ \\
Education & 0.013 & 0.330 \\
Family Member & 0.031 & 0.281 \\
Farming Experience & 0.016 & $0.005^{* *}$ \\
Number of Cattle & 0.122 & $0.001^{* *}$ \\
\hline
\end{tabular}

** Significance at 0.01 
to accept and adopt the technological innovations should be faster.

Farming experience positively influences the beef cattle business efficiency in Tegal Regency $(P<0.01)$. The farmers with longer beef cattle ranching experience may run their business more efficiently. Ozden and Armagan (2014) states that ranching experience may improve the undertaken business efficiency. Isyanto (2013) also adds that ranching experience enables the farmers to have better skills and expertise in managing the beef cattle business to become more efficient. The other aspect is number of cattle which also becomes an important factor to improve the beef cattle business efficiency in Tegal regency $(P<0.01)$. The increasing number of beef cattle may improve the business efficiency. More number of beef cattle may economically lead to the business management efficiency. Bahta and Baker (2015) argue that the increasing livestock capacity maintained may economically result in business which is more efficient. However, it should be considered that the beef cattle business management as a side business has a very limited time due to the availability of the production inputs.

\section{Conclusions}

The small scale cattle business in Tegal Regency has a sufficient business competitiveness characterized by its business efficiency by 1.39. Farmers' age, farming experience, and business scale are the important elements in strengthening the smallscale beef cattle competitiveness in Tegal regency.

The farmers' capacity improvement due to the beef cattle cultivation and business scale addition should be prioritized by the government of Tegal regency to strengthen the competitiveness and sustainability of small scale cattle business in Tegal regency.

\section{References}

Alvarez, A. and C. Arias. 2014. A Selection of Relevant Issues in Applied Stochastic Frontier Analysis. Economics and Business Letters, 3 (1): 3-11.
Bahta, S dan D Baker. 2015. Determinants of Profit Efficiency among Smallholder Beef Producers in Botswana. International Food and Agribusiness Management Review. 18 (3) : 107-129.

Bawinto, A, D.R. Mokoago F.H. Elly, and M.A.V. Manese. 2016. Analisis Break Even Point Ternak Sapi Potong Kelompok Tani "Sumber Hidup Sejati" di Kecamatan Bintauna Kabupaten Bolaang Mongondow Utara. Jurnal Zootek ("Zootek" Journal ). 36 (2).

BPS Kabupaten Tegal. 2016. Kabupaten Tegal dalam Angka 2016. Kab Tegal

Dixon. J, A. Tanyeri-Abur and H. Wattenbach. 2004. Framework for analyzing impacts of globalization on smallholders. AGSF Occasional Paper 5. Food And Agriculture Organization of The United Nations Rome, 2004

Furchan, A.2007.Pengantar Penelitian dalam Pendidikan.Pustaka Pelajar.Yogyakarta.

Hadiana, H.M. 2007. Dampak Faktor Eksternal Kawasan terhadap Efisiensi Usaha Ternak Sapi Perah (Analisis Berdasarkan Fungsi Biaya Frontier) The Impact of Location External Factors on Smallholders Dairying Efficiency (An Analysis Base on Cost Frontier Function). Jurnal Ilmu Ternak, Juni 2007. 7 (1).

Isyanto, Y A., M. Iksan S, N Hanani, and Syafrial. 2013. Measurement of Farm Level Efficiency of Beef Cattle Fattening in West Java Province, Indonesia. Journal of Economics and Sustainable Development. 4 (10).

Iyai D.A, Desni T. R. Saragih, and F.P. Rumbiak. 2016. Effect of Traditional Cattle Farming Systems on Farmer Knowledge, Cattle Performances and Agribusiness Potential in West New GuineaPapua Barat Province,Indonesia. Animal and Veterinary Sciences 2016. 4 (1): 5-10.

Krugman, P.R. dan Obstfeld M. 2000. Ekonomi Internasional Teori dan Kebijaksanaan, Jakarta: Rajawali Press.

Luanmase, C.M., S. Nurtini, dan F. TrisaktiHaryadi. 2011. Analisis Motivasi Beternak Sapi Potong Bagi Peternak Lokal Dan Transmigran Serta Pengaruhnya Terhadap Pendapatan Di Kecamatan Kairatu, Kabupaten Seram Bagian Barat. Buletin Peternakan. 35(2).

Makatita, J. 2013. Hubungan Antara Karakteristik Peternak Dengan Skala Usaha pada Usaha Peternakan Kambing di Kecamatan Leihitu Kabupaten Maluku Tengah. Agrinimal, 3 (2).

Marjaya, S. 2015. Analisis Efisiensi dan Daya Saing Komoditas pada Sistem Usahatani Integrasi Jagung-Sapi di Kabupaten Kupang. Ilmu Pertanian. 18 (3).

Marques, P.R., J.O.J. Barcellos C. McManus, R.P. Oaigen, F.C. Collares, M.E.A. Canozzi, V.N. 
Lampert. 2011. Competitiveness of beef farming in Rio Grande do Sul State, Brazil. Agricultural Systems 104 (2011) 689-693

Mohammed MA and Ortmann GF.2005. Factors Influencing Adoption of Livestock Insurance by Commercial Dairy Farmers in Three Zobatat of Eritrea. Agrekon. 44(2): 172-186.

Otieno, D.J., L. Hubbard and E. Ruto. 2012. Determinants of Technical Efficiency in Beef Cattle Production in Kenya. Paper Presented at The International Association of Agricultural Economists (IAAE) Triennial Conference, Foz do Iguacu, Brazil, August.
Ozden, A and G. Armagan. 2014. Efficiency Analysis On Cattle Fattening In Turkey. Veterinarija Ir Zootechnika (Vet Med Zoot). T. 67 (89) : 88-93

Sanaky, H. 2003. Paradigma Pendidikan Islam: Membangun Masyarakat Madani Indonesia. Yogyakarta: Safiria Insani Press

Zuman, H., J.Setianto, and S. Putra Utama. 2012. Keputusan Peternak Mempertahankan Ternak Sapi Lokal sebagai Usaha Ternak di Kabupaten Kaur. Jurnal Penelitian Pengelolaan Sumberdaya Alam dan Lingkungan. 1(2) : 135-140. 